\title{
PENGARUH LIKUIDITAS DAN PROFITABILITAS TERHADAP KEBIJAKAN DIVIDEN
}

\author{
Keukeu Firda Lestari \\ Universitas Pendidikan Indonesia \\ keukeufirda@gmail.com \\ Heraeni Tanuatmodjo \\ Universitas Pendidikan Indonesia \\ heraenitanuatmodjo@upi.edu \\ Mayasari \\ Universitas Pendidikan Indonesia \\ mayasarilutan@upi.edu
}

\begin{abstract}
The problem of this research was about decrease in dividend policy BUSN Devisa listed on the Indonesia Stock Exchange which is measured by Dividend Payout Ratio (DPR) over the last two years. These factors affecting the dividend policy were liquidity which is measured by Loan to Deposit Ratio (LDR) and profitability which is measured by Return On Equity (ROE). The purposes of this study were describing the liquidity, profitability, dividend policy, the effect liquidity on dividend policy, the effect profitability on dividend policy, and the effect of liquidity and profitability on dividend policy. This research utilised descriptive and verificative, the technique which is used was multiple correlation, and hypothesis testing used $t$ Test (partial significance test) and F Test (simultaneous significance test). The data is gained from secondary data which is from the annual report and summary of performance BUSN Devisa from 20102014. The population of this study was 25 BUSN Devisa listed on the Indonesia Stock Exchange with 4 samples through purposive sampling technique. The result of hypothesis testing in partial showed that liquidity and profitability effected the dividend policy significantly. The result of hypothesis testing showed that the liquidity and profitability effected on dividend policy significant simultaneously.
\end{abstract}

\section{Keywords: Liquidity, Profitability, Dividend Policy PENDAHULUAN}

Kebijakan dividen merupakan salah satu fungsi manajemen keuangan selain dari keputusan investasi dan pendanaan yang dilakukan oleh perusahaan atau perbankan dalam mengambil keputusan mengenai laba yang diperolehnya untuk dibagikan kepada pemegang saham sesuai dengan saham yang dimilikinya sebagai dividen atau diinvestasikan kembali sebagai retained earning yang dilaksanakan berdasarkan Rapat Umum Pemegang Saham (RUPS).

Gitman, L.J. (2009:611) menyatakan bahwa "Kebijakan dividen perusahaan harus dirumuskan dengan dua tujuan dasar yaitu menyediakan pembiayaan yang memadai dan memaksimalkan kekayaan pemilik perusahaan." Banyak investor menganggap kebijakan dividen itu penting karena investor telah menyediakan uang tunai pada perusahaan dengan harapan akhirnya mendapatkan imbalan salah satunya dengan adanya dividen.
Dividen dijadikan sinyal oleh para investor karena dividen merupakan tingkat pengembalian atas investasinya seperti yang diungkapkan Talmor (dalam Baker, H.,K. 2009:165) bahwa "Dividend policy is only one of the financially related decisions that a firm's manager must make. Each of these decisions potentially serves as a signaling device." Yang berarti bahwa kebijakan dividen merupakan salah satu keputusan keuangan yang harus dibuat oleh manajer dimana keputusan ini berfungsi sebagai perangkat sinyal.

Sesuai dengan Gitman, L.J. (2009:611) yang mengungkapkan bahwa pemegang saham melihat dividen sebagai sinyal keberhasilan perusahaan atau perbankan di masa depan, dividen yang stabil dan berkesinambungan merupakan sinyal positif begitu pula sebaliknya. Stabilitas dividen akan meningkatkan kepercayaan investor terhadap perbankan dalam menanamkan dananya. Perbankan yang membayar dividen stabil dari waktu ke waktu kemungkinan dinilai lebih baik daripada perbankan yang membayar dividen berfluktuasi. Hal ini karena, perbankan yang 
membayar dividen stabil mencerminkan kondisi keuangan perbankan tersebut juga stabil dan sebaliknya, perbankan dengan dividen tidak stabil mencerminkan kondisi keuangan perbankan yang kurang baik.

Dinyatakan pula bahwa konsep risk and return juga berlaku untuk kebijakan dividen perusahaan atau perbankan. Sebuah perusahaan atau perbankan yang membayar dividen yang berfluktuasi dari waktu ke waktu akan dipandang berisiko, dan investor akan membutuhkan tingkat pengembalian yang lebih tinggi, yang akan meningkatkan biaya modal perusahaan atau perbankan.

Kebijakan dividen berpengaruh pada pertumbuhan perusahaan, jika perusahaan menahan sebagian besar laba dalam bentuk laba ditahan maka dividen yang dibagikan akan kecil, sebaliknya jika perusahaan memberikan sebagian besar laba dalam bentuk dividen maka dana yang diinvestasikan kembali ke perusahaan akan kecil yang berarti akan menghambat pertumbuhan perusahaan.

Rata-rata kebijakan dividen BUSN Devisa yang terdaftar di BEI sejak tahun 2010 hingga tahun 2014 yang diukur dengan Dividend Payout Ratio (DPR) cenderung menurun mencapai $18,43 \%$, padahal diharapkan kebijakan dividen perbankan stabil atau bahkan meningkat. Pembagian dividen akan mengurangi laba ditahan dan kas yang tersedia di perbankan, tetapi distribusi keuntungan kepada para pemilik adalah tujuan utamanya. Besar kecilnya laba yang dihasilkan untuk setiap tahunnya memengaruhi besarnya kebijakan dividen yang diukur dengan DPR. DPR merupakan salah satu indikator yang digunakan untuk mengukur besarnya laba yang dibagikan sebagai dividen kepada para pemegang saham sesuai dengan saham yang dimilikinya.

Manajemen harus berhati-hati dalam memutuskan kebijakan dividen, karena perubahan kebijakan dividen dapat menyebabkan pemegang saham menjual sahamnya, sehingga menyebabkan harga saham turun. Penurunan harga saham mungkin bersifat sementara, tapi mungkin juga bersifat permanen jika beberapa investor baru tertarik dengan kebijakan dividen baru, maka harga saham akan tetap tertekan. Kebijakan baru akan menarik investor yang bahkan lebih besar dari perusahaan atau perbankan sebelumnya, dalam hal ini harga saham akan naik.

Berdasarkan permasalahan tersebut maka perlu dianalisis faktor-faktor yang dapat memengaruhi kebijakan dividen. Hanafi M.M. (2004:375) mengemukakan bahwa faktor-faktor yang memengaruhi kebijakan dividen yaitu: 1) kesempatan investasi, 2) profitabilitas, 3) likuiditas, 4) akses ke pasar keuangan, 5) stabilitas pendapatan, 6) pembatasan-pembatasan.

Gitman, L.J. (2009:607) menyatakan faktorfaktor yang memengaruhi kebijakan dividen sebagai berikut "Factors affecting dividend policy is legal constraints, contractual constraints, internal constraints, the firm's growth prospects, owner considerations, and market considerations." Sedangkan Utari, D., Ari, P., dan Darsono, P. (2014:250-252) menyatakan bahwa faktor-faktor yang memengaruhi kebijakan dividen yaitu posisi likuiditas, perlunya membayar kembali pinjaman, tingkat perluasan harta, tingkat keuntungan, stabilitas keuntungan, pintu sasaran modal, kontrol, kedudukan pajak pemegang saham.

Pada kenyataan di lapangan profitabilitas dan likuiditas lebih dominan diteliti, seperti Suharli, M. (2007) yang menyatakan bahwa kebijakan jumlah pembagian dividen dipengaruhi oleh profitabilitas dan diperkuat oleh likuiditas. Hasanah, U. (2009) dalam penelitiannya mengatakan bahwa profitabilitas berpengaruh terhadap dividend payout ratio, sedangkan investasi, likuiditas, dan ukuran perusahaan tidak berpengaruh terhadap dividend payout ratio. Kemudian Ahmad, R. (2009) dan Dina, R. (2014) mengemukakan bahwa likuiditas dan profitabilitas memiliki pengaruh terhadap kebijakan dividen. Berdasarkan latar belakang penelitian tersebut maka tujuan penelitian ini adalah untuk memperoleh temuan mengenai:

1. Pengaruh likuiditas terhadap kebijakan dividen BUSN Devisa yang terdaftar di BEI periode 2010-2014.

2. Pengaruh profitabilitas terhadap kebijakan dividen BUSN Devisa yang terdaftar di BEI periode 2010-2014.

3. Pengaruh likuiditas dan profitabilitas terhadap kebijakan dividen BUSN Devisa yang terdaftar di BEI periode 2010-2014.

\section{KAJIAN PUSTAKA}

Manajemen keuangan merupakan bagian dari ilmu manajemen yang menyangkut kegiatan perencanaan, analisis dan pengendalian kegiatan keuangan. Manajemen keuangan menurut Husnan, S. dan Enny, P. (2004:4-6) menyangkut kegiatan perencanaan, analisis, serta pengendalian keuangan. Salah satu fungsi manajemen keuangan adalah keputusan atau kebijakan dividen selain keputusan investasi dan keputusan pendanaan menurut Gitman, L.J., dan Chad, J.Z. (2012:561).

Kebijakan dividen dapat memengaruhi nilai perusahaan dan pada gilirannya, kekayaan pemegang saham (Baker, H.K., Veit, E.T., dan Powell, G.E., 2001). Senada dengan Gitman, L.J. (2009:611) yang menyatakan bahwa "Kebijakan 
dividen memiliki dua tujuan dasar yaitu menyediakan pembiayaan yang memadai dan memaksimalkan kekayaan pemilik perusahaan."

Pembagian dividen yang stabil akan meningkatkan kepercayaan investor dalam menanamkan dananya serta dinilai lebih baik dibandingkan pembagian dividen yang berfluktuasi. Pembagian dividen yang stabil mencerminkan kondisi keuangan stabil, juga dijadikan sebagai sinyal keberhasilan di masa depan. Faktor-faktor yang memengaruhi kebijakan dividen diantaranya likuiditas dan profitabilitas seperti yang diungkapkan Hanafi, M.M. (2004:375).

Banyak investor menganggap kebijakan dividen penting karena investor telah menyediakan uang tunai pada perusahaan dengan harapan akhirnya mendapatkan imbalan salah satunya dengan dividen. Peningkatan atau penurunan dividen sering diartikan sebagai keyakinan manajemen akan prospek perusahaan atau perbankan. Apabila perusahaan atau perbankan meningkatkan pembayaran dividen, hal ini diartikan sebagai harapan manajemen akan membaiknya kinerja perusahaan atau perbankan di masa yang akan datang, begitu pula sebaliknya. Pembagian dividen ini dijadikan sinyal oleh para investor tentang prospek dan risiko perusahaan atau perbankan di masa yang akan datang.

Dalam mengambil keputusan keuangan salah satunya mengambil keputusan atau kebijakan dividen, terlebih dahulu harus memahami kondisi keuangan perusahaan. Untuk memahami kondisi keuangan perusahaan, diperlukan analisis terhadap laporan keuangan perusahaan. Data yang terdapat dalam laporan keuangan digunakan untuk menganalisis rasio keuangan.

Digunakannya analisis rasio keuangan dalam melihat suatu perusahaan akan memberikan gambaran tentang keadaan perusahaan dan dapat dijadikan sebagai alat prediksi bagi perusahaan tersebut di masa yang akan datang. Ini dikarenakan rasio keuangan juga memungkinkan manajer keuangan memperkirakan reaksi kreditor dan investor dalam memperkirakan bagaimana memperoleh kebutuhan dana, serta besarnya dana yang diperoleh.

Para investor menurut Fahmi, I. (2014:115) adalah mereka yang menerapkan konsep "Think fast and decision fast." atau berpikir cepat dan mengambil keputusan secara cepat. Karena faktor itu maka investor menginginkan penggunaan rasio keuangan yang dianggap lebih fleksibel dan sederhana namun memberi jawaban yang mereka inginkan. Rasio keuangan menurut Gitman, L.J., dan Chad, J.Z. (2012:71-83) terbagi menjadi lima yaitu liquidity ratio, activity ratio, debt ratio, profitability ratio, and market ratio.

Berdasarkan faktor yang telah diuraikan likuiditas dan profitabilitas merupakan rasio paling dominan yang dijadikan rujukan para investor untuk melihat kinerja suatu perusahaan atau perbankan. Likuiditas adalah kemampuan suatu perusahaan atau perbankan dalam melunasi kewajiban jangka pendeknya. Semakin tinggi likuiditas berarti semakin tinggi pula dividen yang dibagikan. Indikator likuiditas yang digunakan dalam penelitian ini yaitu LDR dimana semakin tinggi LDR berarti semakin rendah kemampuan likuiditasnya.

Profitabilitas karena berkaitan dengan laba, laba ini yang dijadikan dasar dalam pembagian dividen. Profitabilitas ini diperlukan oleh perusahaan apabila perusahaan akan melakukan pembayaran dividen. Semakin besar profitabilitas maka semakin besar pula dividen yang dibagikan. Indikator profitabilitas yang digunakan dalam penelitian ini adalah ROE. Semakin tinggi ROE maka semakin baik. ROE memiliki arti penting untuk menilai kinerja keuangan perusahaan dalam memenuhi harapan pemegang saham.

Likuiditas dan profitabilitas dapat dikategorikan sebagai sinyal yang dilakukan perusahaan atau perbankan untuk memberi petunjuk kepada investor mengenai prospek perusahaan atau perbankan. Dengan melihat likuiditas dan profitabilitas akan membuat para investor memiliki penilaian terhadap perusahaan atau perbankan sebelum memutuskan untuk menanamkan dananya dengan harapan mendapatkan imbalan berupa dividen.

\section{METODE PENELITIAN}

Penelitian ini dilakukan untuk mengetahui pengaruh likuiditas dan profitabilitas terhadap kebijakan dividen pada BUSN Devisa yang terdaftar di BEI periode 2010-2014 dengan unit analisisnya adalah Loan to Deposits Ratio (LDR), Return On Equity (ROE), dan Dividend Payout Ratio (DPR). Penelitian ini merupakan penelitian deskriptif dan verifikatif. Penelitian ini dilakukan dalam kurun waktu 5 tahun yaitu mulai dari tahun 2010 sampai dengan tahun 2014 maka jangka waktu penelitian ini adalah time series. Dalam penelitian ini yang menjadi populasi adalah 25 BUSN Devisa yang terdaftar di BEI periode 2010-2014 sedangkan yang dijadikan sampel dalam penelitian ini adalah 4 BUSN Devisa yang terdaftar di BEI periode 2010-2014 yaitu: 1) PT. Bank Central Asia, Tbk., 2) PT. Bank Nusantara Parahyangan, Tbk., 3) PT. Bank Danamon Indonesia, Tbk., dan 4) PT. Bank Woori Saudara Indonesia 1906, Tbk. dengan menggunakan teknik purposive sampling. Teknik analisis yang 
dilakukan dalam penelitian ini adalah korelasi parsial dan korelasi multipel, serta pengujian hipotesis dengan menggunakan uji $t$ (uji signifikansi parsial) dan uji F (uji signifikansi simultan).

\section{HASIL DAN PEMBAHASAN}

\section{PENGARUH LIKUIDITAS TERHADAP KEBIJAKAN DIVIDEN}

Berdasarkan penelitian yang telah dilakukan mengenai pengaruh likuiditas terhadap kebijakan dividen dengan dilakukannya analisis korelasi parsial yang tersaji dalam Tabel 1. dan uji signifikansi koefisien korelasi parsial diperoleh bahwa likuiditas yang diukur dengan LDR memiliki pengaruh terhadap kebijakan dividen yang diukur dengan DPR sehingga hipotesis yang diajukan oleh penulis sesuai dan dapat diterima.

TABEL 1.

HASIL KORELASI PARSIAL X1 DENGAN Y APABILA X2 TETAP Correlations

\begin{tabular}{|c|c|c|c|c|}
\hline \multicolumn{5}{|c|}{ Correlations } \\
\hline Control Vari & ables & & Likuiditas & $\begin{array}{c}\text { Kebijakan } \\
\text { Dividen }\end{array}$ \\
\hline \multirow{6}{*}{ Profitabilitas } & \multirow{3}{*}{ Likuiditas } & Correlation & 1.000 & .672 \\
\hline & & $\begin{array}{l}\text { Significance } \\
\text { (2-tailed) }\end{array}$ & . & .002 \\
\hline & & Df & 0 & 17 \\
\hline & \multirow{3}{*}{$\begin{array}{l}\text { Kebijakan } \\
\text { Dividen }\end{array}$} & Correlation & .672 & 1.000 \\
\hline & & $\begin{array}{l}\text { Significance } \\
\text { (2-tailed) }\end{array}$ & .002 & \\
\hline & & Df & 17 & 0 \\
\hline
\end{tabular}

Berdasarkan hasil korelasi parsial diperoleh nilai koefisien sebesar 0,672 antara likuiditas dengan kebijakan dividen apabila profitabilitas tetap dengan arah positif yang berarti semakin tinggi likuiditas maka semakin tinggi kebijakan dividen, begitu pula sebaliknya. Kemudian diperoleh $t_{\text {hitung }}$ 3,7414 lebih besar dibandingkan dengan $t_{\text {tabel }}$ dengan tingkat signifikansi 0,002 yang menunjukkan ada pengaruh likuiditas terhadap kebijakan dividen, serta diperoleh koefisien determinasi sebesar 45,1584\% yang berarti bahwa likuiditas memengaruhi kebijakan dividen sebesar 45,1584\%, sedangkan sisanya $54,8416 \%$ dipengaruhi oleh faktor-faktor lain.

Penelitian ini mendukung Frankfurter, G., M., Bob G. Wood, dan James Wansley (2003:98) menyatakan bahwa "Shareholder liquidity requirements partially determine firm dividend policy." Yang berarti kebutuhan likuiditas pemegang saham sebagian menentukan kebijakan dividen perusahaan. Sesuai dengan penelitian yang telah dilakukan oleh Zameer, H., et.al. (2013) yang menyatakan bahwa likuiditas memiliki hubungan yang sangat signifikan dengan pembagian dividen bank Pakistan. Kemudian Ahmed, I.E. (2014) menyatakan bahwa kebijakan dividen memiliki hubungan linear dengan likuiditas.

\section{PENGARUH PROFITABILITAS TERHADAP KEBIJAKAN DIVIDEN}

Berdasarkan penelitian yang telah dilakukan mengenai pengaruh profitabilitas terhadap kebijakan dividen dengan dilakukannya analisis korelasi parsial yang tersaji dalam Tabel 2. dan uji signifikansi koefisien korelasi parsial diperoleh bahwa profitabilitas yang diukur dengan ROE memiliki pengaruh terhadap kebijakan dividen yang diukur dengan DPR sehingga hipotesis yang diajukan oleh penulis sesuai dan dapat diterima.

\section{TABEL 2.}

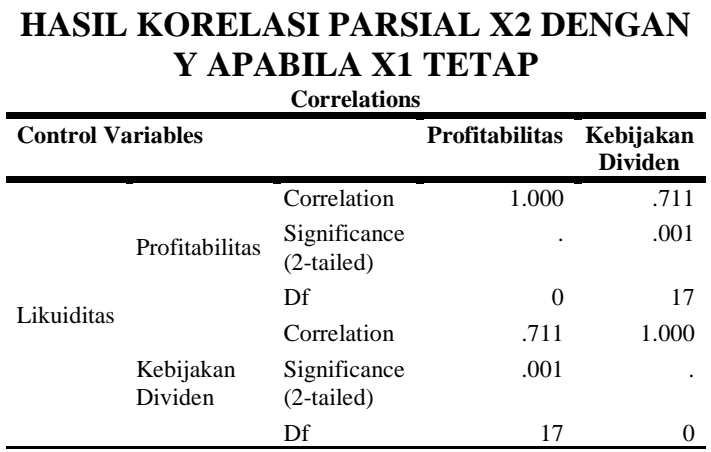

Sumber: Output IBM SPSS 21.0

Berdasarkan hasil korelasi parsial diperoleh nilai koefisien sebesar 0,711 antara profitabilitas dengan kebijakan dividen apabila likuiditas tetap dengan arah positif yang berarti semakin tinggi profitabilitas maka semakin tinggi kebijakan dividen, begitu pula sebaliknya. Kemudian diperoleh $t_{\text {hitung }}$ 4,1688 lebih besar dibandingkan dengan $t_{\text {tabel }}$ dengan tingkat signifikansi 0,001 yang menunjukkan ada pengaruh profitabilitas terhadap kebijakan dividen, serta diperoleh koefisien determinasi sebesar 50,5521\% yang berarti bahwa profitabilitas memengaruhi kebijakan dividen sebesar 50,5521\%, sedangkan sisanya $49,4479 \%$ dipengaruhi oleh faktor-faktor lain.

Penelitian ini mendukung Christian Andres (dalam Baker, H., K. 2009:49) menyatakan "Dividend payments are significantly driven by the firms' profitability" yang berarti pembayaran dividen secara signifikan didorong oleh profitabilitas perusahaan. Sesuai dengan penelitian yang telah dilakukan oleh Suharli, M. (2007) yang menyatakan bahwa kebijakan jumlah pembagian dividen dipengaruhi oleh 
profitabilitas. Ahmad, R. (2009) menyatakan bahwa profitabilitas berpengaruh secara signifikan terhadap kebijakan dividen. Hutagalung, S., et.al (2013) menyatakan bahwa terdapat hubungan positif antara kebijakan dividen dan profitabilitas.

\section{PENGARUH LIKUIDITAS DAN PROFITABILITAS TERHADAP KEBIJAKAN DIVIDEN}

Berdasarkan penelitian yang telah dilakukan mengenai pengaruh likuiditas dan profitabilitas terhadap kebijakan dividen, ditemukan bahwa likuiditas yang diukur dengan LDR, profitabilitas yang diukur dengan ROE secara simultan memiliki pengaruh terhadap kebijakan dividen yang diukur dengan DPR dengan dilakukannya analisis korelasi multipel yang tersaji dalam Tabel 3. dan uji signifikansi koefisien korelasi multipel sehingga hipotesis yang diajukan oleh penulis sesuai dan dapat diterima.

TABEL 3.

HASIL KORELASI MULTIPEL

\begin{tabular}{|c|c|c|c|c|c|c|c|c|c|}
\hline \multicolumn{10}{|c|}{ Model Summary } \\
\hline \multirow[b]{2}{*}{ Model } & \multirow[b]{2}{*}{$\mathbf{R}$} & \multirow[b]{2}{*}{$\begin{array}{c}\mathbf{R} \\
\text { Square }\end{array}$} & \multirow[b]{2}{*}{$\begin{array}{c}\text { Adjusted } \\
\mathbf{R} \\
\text { Square }\end{array}$} & \multirow{2}{*}{$\begin{array}{c}\text { Std. } \\
\text { Error of } \\
\text { the } \\
\text { Estimate }\end{array}$} & \multicolumn{5}{|c|}{ Change Statistics } \\
\hline & & & & & $\begin{array}{c}\mathbf{R} \\
\text { Square } \\
\text { Change }\end{array}$ & $\begin{array}{c}F \\
\text { Change }\end{array}$ & df1 & df2 & $\begin{array}{c}\text { Sig. F } \\
\text { Change }\end{array}$ \\
\hline 1 & $.717^{\mathrm{a}}$ & .515 & .458 & 6.79904 & .515 & 9.013 & 2 & 17 & .002 \\
\hline
\end{tabular}

Sumber: Output IBM SPSS 21.0

Berdasarkan hasil korelasi multipel diperoleh nilai koefisien sebesar 0,717 dan nilai $\mathrm{R}$ Square 0,515 antara likuiditas dan profitabilitas dengan kebijakan dividen. Kemudian diperoleh $F_{\text {hitung }}$ 5,9576 lebih besar dibandingkan dengan $F_{\text {tabel }}$ dengan tingkat signifikansi 0,002 yang menunjukkan bahwa likuiditas dan proftabilitas berpengaruh secara simultan terhadap kebijakan dividen, serta diperoleh koefisien determinasi sebesar 51,4089\% yang berarti bahwa likuiditas dan profitabilitas memengaruhi kebijakan dividen sebesar $51,4089 \%$, sedangkan sisanya $48,5911 \%$ dipengaruhi oleh faktor-faktor lain.

Pengaruh likuiditas dan profitabilitas terhadap kebijakan dividen telah dibuktikan dimana didukung penelitian yang dilakukan oleh Suharli, M. (2007) yang menyatakan bahwa kebijakan jumlah pembagian dividen perusahaan dipengaruhi oleh profitabilitas dan diperkuat oleh likuiditas perusahaan. Sandy, A. (2013) yang menyatakan bahwa secara simultan likuiditas dan profitabilitas memengaruhi kebijakan dividen. Zameer, H., et.al (2013) menyatakan bahwa likuiditas dan profitabilitas menunjukkan hubungan yang signifikan dengan pembagian dividen bank Pakistan. Serta Olowe, R.A., dan Soyoye L.M. (2014) menyatakan bahwa likuiditas dan profitabilitas merupakan faktor yang memengaruhi pembayaran dividen.

\section{KESIMPULAN}

Berdasarkan hasil analisis dan pembahasan yang telah dilakukan maka dapat ditarik kesimpulan diantaranya yaitu:

1. Berdasarkan hasil korelasi parsial dan uji signifikansi koefisien korelasi parsial menunjukkan bahwa likuiditas berpengaruh terhadap kebijakan dividen yang berarti bahwa besar kecilnya dividen yang dibagikan 4 BUSN Devisa dipengaruhi oleh likuiditas perbankan, dengan arah pengaruhnya positif yang berarti semakin tinggi likuiditas maka semakin tinggi kebijakan dividennya, begitu pula sebaliknya.

2. Berdasarkan hasil korelasi parsial dan uji signifikansi koefisien korelasi parsial menunjukkan bahwa profitabilitas berpengaruh terhadap kebijakan dividen yang berarti bahwa besar kecilnya dividen yang dibagikan 4 BUSN Devisa dipengaruhi oleh profitabilitas perbankan, dengan arah pengaruhnya positif yang berarti semakin tinggi profitabilitas maka semakin tinggi kebijakan dividennya begitu pula sebaliknya.

3. Berdasarkan hasil korelasi multipel dan uji signifikansi koefisien korelasi multipel menunjukkan bahwa likuiditas dan profitabilitas secara simultan berpengaruh terhadap kebijakan dividen yang berarti bahwa besar kecilnya dividen yang dibagikan 4 BUSN Devisa dipengaruhi oleh likuiditas dan profitabilitas perbankan.

\section{REFERENSI}

Ahmad, R. (2009). Pengaruh Profitabilitas dan Investment Opportunity Set Terhadap Kebijakan Deviden Tunai. Jurnal Ilmiah Abdi Ilmu, 2(2), hlm 188-201.

Ahmed, I.E. (2014). The Impact of Liquidity on the Dividends Policy. Proceedings of 26th International Business Research Conference, pp 1-12.

Baker, H. K., Veit, E. T., Powell, G. E. (2001). Factors influencing dividend policy decisions of Nasdaq firms. The Financial Review. Journal of Business and Economics, 38(2), pp 17-27.

Baker, H., K. (2009). Dividends and Dividend Policy. Canada: John Wiley \& Sons, Inc.

Dina, R. (2014). Pengaruh Likuiditas dan Profitabilitas Terhadap Kebijakan Dividen Pada Perusahaan Manufaktur 
yang listed di Bursa Efek Indonesia pada tahun 2012. Bandung: UPI.

Fahmi, I. (2014). Analisis Laporan Keuangan. Bandung: Alfabeta.

Frankfurter, G., M., Bob G. Wood, dan James Wansley. (2003). Dividend Policy Theory and Practice. USA: Academic Press.

Gitman, L.J. (2009). Principles Of Managerial Finance (twelfth edition). USA: Pearson.

Gitman, L.J. dan Chad J.Z. (2012). Principle of Managerial Finance (thirteenth ed.). USA: Pearson.

Hanafi, M. M. (2004). Manajemen Keuangan. Yogayakarta: BPFE.

Hasanah, U. (2009). Analisis pengaruh investasi, likuiditas, profitabilitas, dan ukuran perusahaan terhadap kebijkan dividend payout ratio pada perusahaan yang terdaftar di JII periode 2000-2004. Yogyakarta: UIN Sunan Kalijaga.

Husnan, S., Enny, P. (2004). Dasar-Dasar Manajemen Keuangan. Yogyakarta: UPP AMP YPKN.

Hutagalung, S., et.al. (2013). The Dividend Payout Policy - A Study on Malaysian Financial Institutions. Pertanika J. Soc. Sci. and Hum, 21 (S), pp 127 - 148.

Olowe, R.A., Soyoye, L.M. (2014). Determinants of Dividend Payout in the Nigerian Banking Industry, pp 1-23.

Sandy, A. (2013). Pengaruh Profitabilitas dan Likuiditas Terhadap Kebijakan Dividen Kas Pada Perusahaan Otomotif. Jurnal Ilmu Dan Riset Akuntansi, 1(1), hlm. 5876.

Suharli, M. (2007). Pengaruh Profitability dan Investment Opportunity Set Terhadap Kebijakan Dividen Tunai dengan Likuiditas Sebagai Variabel Penguat (Studi pada Perusahaan yang Terdaftar di Bursa Efek Jakarta Periode 20022003). Jurnal Akuntansi dan Keuangan, 9 (1), hlm. 9-17.

Utari, D., Ari, P., Darsono, P. (2014). Manajemen Keuangan Kajian Praktik dan Teori dalam Mengelola Keuangan Organisasi Pemasaran. Jakarta: Mitra Wacana Media.

Zameer, H. et.al. (2013). Determinants of Dividend Policy: A Case of Banking Sector in Pakistan. Middle-East Journal of Scientific Research, 18 (3), pp 410424. 